\title{
Workforce Analysis from an Accounting Perspective: What Do the Determinants Really Demand?
}

\author{
Tuğba Koç1 $\odot$, Bilge Katanalp2 $\odot$, Adem Akbiyik 3 ๑
}

\begin{abstract}
Each profession has its own criteria. Of all the management disciplines, the employment trend in the field of accounting best reflects the state of recruitment of professionals. Thus, we need to examine what each profession expects from accountants. Using text analysis via Wordstat, we analyze 7,320 pre-accounting job advertisements to find the overall job specification of the sector for a pre-accounting employee. Of the 25 criteria identified, 12 were found common in the literature, local standards, and the sector. From our findings, the Turkish sector is more adapted to international than local standards, indicating that local standards were set without consulting the employers. This study further confirms that soft skills are as important as technical skills. Additionally, women are more likely to be recruited to a pre-accountant position during their 10-year study period. Turkey is a Eurasian country that is influenced by both Asian and European countries and their respective profession-related norms and practices. Thus, our findings may be generalizable. Overall, policymakers need to pay attention to the employers' opinions before establishing local standards..
\end{abstract}

Keywords

Job Ads Analysis, Accounting Graduate Competencies, Text Mining

\section{Introduction}

University business departments are strongly related to the management side of organizations. Management is considered to be a science rather than a series of actions (Hughes et al., 2008). Business departments generally focus on theoretical aspects rather than practical implications. They help to develop rigor, but not relevant real-world applications (Bennis and O'Toole, 2005; Augier and March, 2007). Thus, the essential skills that employers expect are not easy to acquire, especially for business students. Kaplan (2011) considers it critical to reveal the expected competencies of an accounting graduate because, of all the management disciplines, employment trends in the field of accounting best reflect the state of recruitment

1 Tuğba Koç (Res. Asst. Dr.), Sakarya University, Faculty of Business Administration, Department of Management Information Systems, Sakarya, Turkey. E-mail: tcekici@sakarya.edu.tr ORCID: 0000-0002-2454-9992

2 Corresponding Author: Bilge Katanalp (Res. Asst.), Sakarya University, Faculty of Business Administration, Department of Management Information Systems, Sakarya, Turkey. E-mail: bilgeonal@sakarya.edu.tr ORCID: 0000-0002-7274-4127

3 Adem Akbiyik (Assoc. Prof. Dr.), Sakarya University, Faculty of Business Administration, Department of Management Information Systems, Sakarya, Turkey. E-mail: adema@sakarya.edu.tr ORCID: 0000-0001-7634-4545

To cite this article: Koc, T., Katanalp, B., \& Akbiyik, A. (2021). Workforce Analysis from an Accounting Perspective: What do the Determinants Really Demand? Istanbul Business Research, 51(1) Advanced Online Publication. http://doi.org/10.26650/ibr.2021.51.972067 
of professionals. The literature claims a general dissatisfaction with the profile of accounting graduates due to the gap between their acquired and required skills (Lin, Xiong, and Liu, 2005; De Lange, Jackling, and Gut, 2006; Kavanagh and Drennan, 2008). However, recent studies do not agree on how to fix this gap. Some studies (Webb and Chaffer, 2016; Bayerlein and Timpson, 2017) have proven the existence of the gap, but with the claim that it is not as pervasive as was once thought (Low, Botes, Rue, and Allen, 2016). Low et al. (2016) point out that universities are doing their best in academic terms to train their accounting students adequately. Nevertheless, the required skills and competencies for accounting graduates remain a critical issue in the Turkish business sector. Employers find the universities' academic accounting departments inadequate in providing practical training (Coşkun, Kır, and Coşkun, 2017; Y1ld1z, 2017).

Bui and Porter (2010) identified four main reasons why accounting graduates fail to gain the desired competencies: (a) students' dissatisfaction with accounting education, (b) conflict between what is taught and ongoing research, (c) traditional educators and an outdated curricula, and (d) fast changes in the global market but slow changes in accounting education (i.e., expectation-performance gap). These four reasons are logically linked. As examples for reasons (b) to (d), if an academician has positioned himself/herself as a researcher (b), he/she will not want to become an innovative educator. Such academicians may even be resistant to new educational approaches. Thus, their (c) students will inevitably be dissatisfied (a). Finally, when these dissatisfied students graduate, they will not be able to meet the expectations of potential employers (d). To overcome this situation, researchers have over the last three decades made several attempts to identify the competencies that employers expect of an accounting student (Tan and Laswad, 2018). The problem is that most of the related studies were conducted in the setting of developed countries. To address this concern, Kenny and Larson (2018) categorized 411 papers published in one of the top accounting journals - Advances in International Accounting-during the 30-year period from 1987 to 2016 by researchers' focus and methodology, chosen country, and authorship diversity. They found that while the origin of the studies was predominantly in the United States initially, other European countries such as France, Germany, and the United Kingdom started their research after 1999, causing the total percentage of studies in the United States to drop from 57.5\% to $37.2 \%$. They found that only $0.4 \%$ of the studies were conducted in Turkey, all of them in early 1999 . Moreover, a general need and ongoing call arose for empirical studies on accounting graduate requirements in the context of developing countries (Ahmad and Gao, 2004; Awayiga, Onumah, and Tsamenyi, 2010). Additionally, Norain et al. (2018) emphasized the need to identify the expected competencies of accounting graduates and understand the evolving requirements of the industry in developing countries. This required consistent engagement with the industry. Therefore, research should be conducted with real, up-to-date, and longitudinal data. This leads us to another problem. Accounting studies generally use traditional methods such as 
surveys, focus groups, and interviews. Rebele and St. Pierre (2015) lamented the stagnation of accounting research and its loss of "hype"; most of the studies they examined used the survey research method and focused on the same general topics.

To avoid this conventional approach, researchers are now using different methods to identify the employability skills required in accounting. Content analysis is an unobtrusive technique used popularly in recent years when more detailed information is required on different categories (Willcoxson, Wynder, and Laing, 2010). France (2010) collected 335 accounting job ads from Australasian organizations and analyzed them using this technique. The results contradict contemporary pedagogical assumptions, emphasizing the need for communication and problem-solving skills. Dunbar, Laing, and Wynder (2016) conducted a similar study to investigate the expected technical and soft skills of accounting graduates from the employers' perspective. They collected 1,594 job advertisements from 2006 to 2009 from a major newspaper in Queensland, Australia. They used content analysis to find that soft skills are more important than technical skills. Tan and Laswad (2018) also used a novel content analysis approach to find the employability skills required for accounting graduates in Australasia. They provided evidence that strong team work and good communication skills are the most valuable behavioral skills employers perceive. Although their findings slightly differ for the five accounting occupational subgroups, interpersonal and personal skills commonly appear to be the most sought-after requirement. They stated that this finding emphasizes the changing nature of the accountant's job profile from an occupation to a more "respected" profession. They made several recommendations for accounting academics, including helping students to develop appropriate soft skills. Although their research allows for a comprehensive comparison between two different countries and accounting subgroups, the dataset covers only one year (July 2015 to June 2016). While some attempts have been made in the Turkish literature to identify the expected competencies of accounting graduates (Yürekli and Gönen, 2015; Coşkun et al., 2017; Yıldız, 2017), only one of them focused on job advertisements, but this followed a structured methodology (Şengel, 2011). Şengel (2011) presents the descriptive statistics of accounting job ads, and nothing more.

In addition to the literature, the accounting professional bodies of different countries, namely, the Accounting and Auditing Standards Authority (Turkey), CPA Australia, the Accounting Standards Committee (Germany), and the Accounting Association Pathways Commission (United Kingdom), have also tried to identify the skills that accounting graduates must have to satisfy their own countries' conditions and to guide the universities' accounting departments. This indicates that accounting curricula can be designed in accordance with the determined needs.

The original aspects of this study include its data coverage (nine years data and 7,320 job adverts), chosen country (in response to Awayiga et al, 2010; Turkey is a developing co- 
untry), methodology (content analysis), and interpretation of results, thereby identifying the employers' expectations. We also compared the identified skills with findings in the literature and the local standards' suggested skills (Table 6). The particular aspect that makes this work internationally significant relates to Turkey's efforts to create and extend local professional standards - a process influenced by both Western and Eastern cultures. This situation is expected to lead to differences in interactions between professional standards, sector expectations, and education curricula.

As regards to these concerns, we highlight the competencies required for accounting graduates in the context of Turkey, a developing country, using an unobtrusive technique. Unlike most previous studies, which used surveys, interviews, and focus groups, we adopted content analysis, focusing on 7,320 job advertisements posted from 2008 to 2016. Dunbar et al. (2016) used a small number of data samples, while Tan and Laswad (2018) covered only one year. We made a significant effort to gain insight into the alleged gap between accounting standards and employers' expectations in Turkey. This is a relatively new research area, especially in developing countries. We focused primarily on the pre-accounting position since this is considered an initial step toward an accounting career in Turkey (Atagan Çetin, 2017). We also examined whether the required skills uncovered matched the findings in the literature and the local, vocational accounting standards (i.e., the Vocational Qualifications Authority for Accounting Professional Standards, VQAAPS) in Turkey. For this, we formulated the following three research questions:

RQ1: What job skills do employers expect accounting graduates to possess to hold an entry-level pre-accounting position in Turkey?

RQ2: Do the employers' expected entry-level job skills of accounting graduates in Turkey differ from the literature's suggested skills?

RQ3: Do the employers' expected job skills for the accounting profession in Turkey differ from those of the VQAAPS?

The remainder of this paper is organized as follows. We briefly introduce the Turkish VQAAPS in Section 2. We then discuss the accounting graduates' skills and attributes and summarize our analysis of the literature in Section 3. We discuss our research methodology and the dataset in Section 4. Our results are presented in Section 5. We summarize our findings and compare the three perspectives (the literature, local standards, and the sector) in Section 6. We discuss our conclusions in Section 7, and finally present the study's limitations and recommendations for further studies in Section 8.

\section{Turkish VQAAPS}

The International Labor Organization (ILO) created the International Standard Classification of Occupations, gathering data of the three segments of the labor market: employers, 
employees, and governments. With 187 member states, the ILO sets standards for the labor sector and guides governments to develop appropriate policies (ILO, 2019). According to the ISCO-08 published by ILO, a job is "a set of tasks and duties performed, or meant to be performed, by one person, including for an employer or in [the context of] self-employment" (ILO, 2016). The ILO has created a list of English job titles to match the different ISCO-08 codes. For example, eight different job titles for pre-accounting jobs match code ISCO-084311, which we examine in this study. This is important because employers use different job titles in their job advertisements. The ILO list helps us to understand which job title relates to which standard. However, the VQAAPS provides only one job title for the pre-accounting profession. This indicates that the international vocational standards (the International Standard Classification of Occupations by ILO) are too general, with no specific features for comparison but general codes and classifications. National standards are generally derived from this and yet are more specific. This is the main reason why we focused on the VQAAPS rather than international vocational standards.

A foundation in Turkey called the "professional competency board" formed the VQAAPS based on the ILO standards. Figure 1 illustrates how national standards are formed.

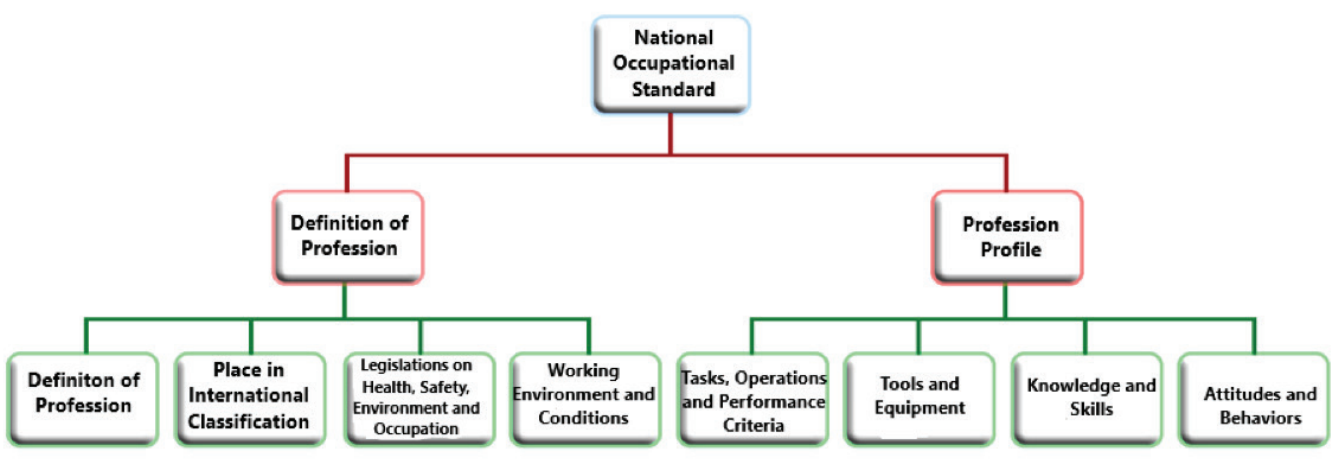

Figure 1. The VQAAPS framework

The scope of this study allows us to investigate only the professional profiles of preaccounting employees. A professional profile refers to the job skills of an employee, and captures four different criteria, as can be seen in the figure.

\section{Skills And Attributes of Accounting Graduates}

Value-added activities, quick and accurate decision making, real-time data acquisition, decisive action, and many other technology-related competencies have become more relevant to companies than ever before. Rapidly developing technologies and the widespread adoption of new, existing technologies have significantly changed the structure of business (Shankar 
et al., 2010), with the employers' expectations evolving simultaneously (McMurray et al., 2016). According to Bancino and Zevalkink (2007), necessity for improvement to the bottom line, increasing competition, and globalization are the three main forces behind employers' demand for a broader skill-set for employees. According to Mohamed and Lashine (2003), rapid changes in the business environment have created an "expectation-performance gap" (Bui and Porter, 2010) between the fast changes in the global market and slow changes in accounting education. This implies the need to enhance the competence level of accountants.

Stone et al. (2013) suggested that global economies and technology force accountants to gain new competencies, of which communication skill is the most essential. However, accounting education worldwide is failing to keep pace with today's dynamic, global business expectations (Awayiga, Onumah and Tsamenyi, 2010). Both early (Simons and Higgins, 1993; Morgan, 1997) and recent (Abayadeera and Watty, 2014; Tempone et al., 2012; Paguio and Jackling, 2016) studies have suggested that employers are generally satisfied with the technical skills or cognitive intelligence levels (e.g., computer-related skills, accounting problem analysis, and specific knowledge on financial matters) of accounting graduates. However, when it comes to soft skills, employers' expectations are seldom met. According to CPA Australia (2019), soft skills can be categorized into four groups: intellectual (e.g., unstructured problem solving and logical and analytical thinking), organizational and business management (e.g., leadership and decision making), interpersonal and communication (e.g., teamwork and verbal/written communication), and personal (e.g., self-management and initiative) skills. Employers can generally assume that every accounting graduate has gained some basic accounting skills from their education. However, soft skills are rarely found, making them more critically required (Atanasovski, Trpeska and Lazarevska, 2018). Yaşar (2019) strongly suggests that soft skills are a "must have," and not just a "nice to have," indicating their importance. Similarly, a recent study evaluated the employers' expectations of skills held by accounting graduates. The study found accounting graduates lacking in social and communication skills (Coşkun, Kır and Coşkun, 2017). Employers expect accounting graduates to improve their critical soft skills and become competent.

With the increased reliance on information technology (IT), the necessity of soft skills is growing, to become as important as technical skills (Crawford, Helliar and Monk, 2011). De Villiers (2010) explored the balance between technical and soft skills in terms of employment in the accounting field. They suggested five main soft skill types: communication, problem solving and critical thinking, leadership and teamwork, ethical and moral values, and selfmanagement. According to de Villiers (2010), the importance of soft skills is increasing, with the stakeholders considering these abilities as critical as technical skills in the recruitment process. Jones and Abraham (2009) examined the expanded role of accountants, to find that some particular soft skills are important for workplace success. According to the International Federation of Accountants (IFAC, 2003) standards, accounting graduates should be required 
to fulfill ten main criteria (i.e., communication, intellectual, interpersonal, technical, personal, organizational and business management, and IT skills; and general, organizational and business, and accounting and auditing knowledge) that employers seek during recruitment. In Australia, practitioners reported that communication, teamwork, and self-management are the most critical skills for accounting graduates for recruitment, training, and ongoing employment purposes (Tempone et al., 2012). However, Coetze and Oberholzer (2009) found the accounting graduates unable to apply their newly acquired knowledge and abilities in the workplace. This is a real problem for employers, and it is contrary to Jackling and De Lange's (2009) new definition of accounting professionals as "knowledge specialists"' (Tempone et al., 2012). From the practitioners' perspective, soft skills for accounting graduates are more an obligatory rule than necessity. However, soft skills are rarely embedded in higher accounting education curricula in Turkey. In this context, Yaşar (2019) uncovered the inadequacies in the accounting education curriculum in Turkey, suggesting a new competency-focused education framework comprising soft skills as well as technical skills (Başar, 2005).

Ahmad and Gao (2004) suggest that the accounting curricula's design has often been ignored, because no evidence seems to suggest that sufficient attention has been given to the necessary general skills as identified by the IFAC (2003). The curricula in universities focus on technical skills, and so the accounting graduates throughout their university years diverge from lifelong learning. This is often accepted as a key learning outcome (Hancock, Howieson and Kent, 2009), and students neglect to improve their soft skills. Similarly, Millard (2003) found that students consider accounting work dull and uninteresting. This is also related to the expectation-performance gap between the value judgment of students and their employers (Marshall, Dombroski, Garner, and Smith, 2010; Low et al., 2016). A detailed and comprehensive study conducted by Kim, Ghosh, and Meng (1993) suggests that motivation or interest in the job is the most dominant factor from the employers' perspective. However, for students, their examination results are the most important criterion for a successful accounting career. As Kavanagh and Drennan (2008) stated, students are becoming more aware of their employers' expectations in terms of analytical, professional, and teamwork skills. However, the curricula do not sufficiently meet these expectations. In their study, Francisco and Kelly (2002) extended Albrecht and Sack's (2000) approach, agreeing that accounting students concur with their employers on the skills necessary for accounting graduates. Furthermore, Oussii and Klibi (2017) empirically found that even though students know the importance of developing their soft skills, they often feel that they cannot develop their aptitudes under the current education system, and that it is unlikely for them to ever find an opportunity to develop their soft skills efficiently. In short, while technical skills development is always part of a well-rounded accounting education, there is no doubt that soft skills are also necessary in today's business environment. According to Jackling and Watty (2010) and Tempone et al. (2012), the literature suffers from lack of studies on the relationship between contextual 
issues and soft skills in the accounting field. Thus, we cannot say that the employers' expectations on soft skills development in accounting education have been adequately considered. Tempone et al. (2012) encouraged researchers to take up this issue in a more nuanced manner. Thus, we present our first research question below:

RQ1: What job skills do employers expect accounting graduates to possess in order to hold an entry-level pre-accounting position in Turkey?

However, no consensus has been reached on the accounting graduates' expected skills. Table 1 summarizes the relevant literature on the suggested vocational skills that an accounting graduate should have from various country perspectives with the recommended attributes, differences, and similarities.

Table 1

Summary of recommended skills for accounting students from different perspectives

\begin{tabular}{|c|c|c|c|c|}
\hline Study & Country & Method & Participants & Required skills \\
\hline \multirow{2}{*}{$\begin{array}{l}\text { Kavanagh } \\
\& \text { Drennan } \\
((2008\end{array}$} & \multirow[b]{2}{*}{ Australia } & $\begin{array}{l}\text { Quantitative } \\
\text { ((Survey }\end{array}$ & $\begin{array}{l}\text { Accounting } \\
\text { students }\end{array}$ & $\begin{array}{l}\text { Continuous learning, decision-making, verbal communi- } \\
\text { cation }\end{array}$ \\
\hline & & $\begin{array}{l}\text { Qualitative } \\
\text { (Focus group } \\
\text { (and interview }\end{array}$ & Employers & $\begin{array}{l}\text { Analytical problem solving, business awareness and real } \\
\text { life experience, technical knowledge }\end{array}$ \\
\hline$(\operatorname{Lin}(2008$ & China & $\begin{array}{l}\text { Quantitative } \\
\text { ((Survey }\end{array}$ & $\begin{array}{l}\text { Accounting } \\
\text { students } \\
\text { Employers } \\
\text { Educators }\end{array}$ & $\begin{array}{l}\text { Core accounting knowledge, business skills, personal } \\
\text { characteristics, business knowledge, basic techniques, } \\
\text { general knowledge }\end{array}$ \\
\hline $\begin{array}{l}\text { Wells, } \\
\text { Gerbic, } \\
\text { Kranenburg, } \\
\text { \& Bygrave } \\
\text { ((2009 }\end{array}$ & $\begin{array}{l}\text { New } \\
\text { Zealand }\end{array}$ & $\begin{array}{c}\text { Quantitative } \\
\text { ((Survey } \\
\text { Qualitative } \\
\text { ((Interview }\end{array}$ & $\begin{array}{c}\text { Experienced } \\
\text { accounting } \\
\text { graduates } \\
\text { Employers }\end{array}$ & $\begin{array}{l}\text { Personal, intellectual and interpersonal abilities such as } \\
\text { pressure management, respond to clients' requirements in } \\
\text { a timely manner }\end{array}$ \\
\hline \multirow{3}{*}{$\begin{array}{l}\text { Jackling \& } \\
\text { de Lange } \\
((2009\end{array}$} & \multirow{3}{*}{ Australia } & \multirow{3}{*}{$\begin{array}{l}\text { Quantitative } \\
\text { ((Survey } \\
\text { Qualitative } \\
\text { ((Interview }\end{array}$} & $\begin{array}{l}\text { Accounting } \\
\text { graduates }\end{array}$ & $\begin{array}{l}\text { Accounting problem analysis, technological skills, tech- } \\
\text { nical skills }\end{array}$ \\
\hline & & & Employers & $\begin{array}{l}\text { Technical accounting knowledge, leadership, verbal com- } \\
\text { munication, interpersonal and team skills }\end{array}$ \\
\hline & & & Educators & $\begin{array}{l}\text { Technical knowledge, intellectual capability, thinking } \\
\text { skills }\end{array}$ \\
\hline \multirow{3}{*}{$\begin{array}{l}\text { Bui \& Porter } \\
((2010\end{array}$} & \multirow{3}{*}{$\begin{array}{l}\text { New } \\
\text { Zealand }\end{array}$} & \multirow{3}{*}{$\begin{array}{l}\text { Qualitative } \\
\text { ((Interview }\end{array}$} & Employers & $\begin{array}{l}\text { Technical accounting knowledge, verbal communication, } \\
\text { writing skills, interpersonal skills, teamwork, advanced } \\
\text { technological skills, lifelong learning, self-confidence }\end{array}$ \\
\hline & & & $\begin{array}{l}\text { Accounting } \\
\text { students }\end{array}$ & $\begin{array}{c}\text { Communication skills, team-work, real-word practice, } \\
\text { intellectual abilities }\end{array}$ \\
\hline & & & $\begin{array}{l}\text { Accounting } \\
\text { graduates }\end{array}$ & Writing skills, applying knowledge to practical situations \\
\hline \multirow{2}{*}{$\begin{array}{l}\text { Awayiga, } \\
\text { Onumah, \& } \\
\text { Tsamenyi } \\
\text { ((2010 }\end{array}$} & \multirow{2}{*}{ Ghana } & \multirow{2}{*}{$\begin{array}{l}\text { Quantitative } \\
\text { ((Survey }\end{array}$} & Employers & $\begin{array}{l}\text { Analytical and critical thinking, computing technology, } \\
\text { professional demeanor }\end{array}$ \\
\hline & & & $\begin{array}{l}\text { Accounting } \\
\text { graduates }\end{array}$ & $\begin{array}{l}\text { Analytical and critical thinking, communication skill, } \\
\text { professional demeanor }\end{array}$ \\
\hline (Jones $(2011$ & America & $\begin{array}{l}\text { Quantitative } \\
\text { ((Survey }\end{array}$ & Employers & Writing skills, effective documentation \\
\hline
\end{tabular}




\begin{tabular}{|c|c|c|c|c|}
\hline Study & Country & Method & Participants & Required skills \\
\hline $\begin{array}{l}\text { Tempone, } \\
\text { Kavanagh, } \\
\text { Segal, Han- } \\
\text { cock, Howi- } \\
\text { eson, \& Kent } \\
\text { ((2012 }\end{array}$ & Australia & $\begin{array}{l}\text { Qualitative } \\
\text { ((Interview }\end{array}$ & Employers & $\begin{array}{l}\text { Communication, teamwork, self-management, initiative } \\
\text { and enterprise, problem solving and planning }\end{array}$ \\
\hline (Jones (2014 & UK & $\begin{array}{l}\text { Qualitative } \\
\text { ((Case study }\end{array}$ & Employers & $\begin{array}{l}\text { Communication, technical skills, team working, commer- } \\
\text { cial/business awareness, professional credibility, and X } \\
\text {.factors skills such as confidence, common sense etc }\end{array}$ \\
\hline $\begin{array}{l}\text { Tanaka } \\
\& \text { Sithole } \\
((2015\end{array}$ & $\begin{array}{l}\text { Swazi- } \\
\text { land }\end{array}$ & $\begin{array}{l}\text { Quantitative } \\
\text { ((Survey }\end{array}$ & Employers & Technical knowledge and technological skills \\
\hline $\begin{array}{l}\text { Ali, Kamaru- } \\
\text { din, Suriani, }\end{array}$ & & Quantitative & Educators & $\begin{array}{l}\text { Writing skill, analytical/critical thinking, teamwork, finan- } \\
\text { cial accounting }\end{array}$ \\
\hline $\begin{array}{l}\text { Saad, \& Af- } \\
\text { (andi }(2016\end{array}$ & Malaysia & ((Survey & Employers & $\begin{array}{l}\text { Resource management, foreign language, risk manage- } \\
\text { ment, financial accounting }\end{array}$ \\
\hline $\begin{array}{l}\text { Hancock, } \\
\text { Freeman, } \\
\text { Watty, Birt, } \\
\text { \& Tyler } \\
((2016\end{array}$ & Australia & $\begin{array}{l}\text { Qualitative } \\
\text { ((Report }\end{array}$ & $\begin{array}{l}\text { Accounting } \\
\text { academics }\end{array}$ & $\begin{array}{c}\text { Possible solutions to routine problems (judgement), } \\
\text { integrate theoretical and technical knowledge, critical } \\
\text { analysis and problem solving, communication, teamwork, } \\
\text { self-management }\end{array}$ \\
\hline $\begin{array}{l}\text { Low, Botes, } \\
\text { Rue, \& Allen } \\
((2016\end{array}$ & $\begin{array}{l}\text { New } \\
\text { Zealand }\end{array}$ & $\begin{array}{l}\text { Qualitative } \\
\text { ((Interview }\end{array}$ & Employers & $\begin{array}{c}\text { Interpersonal and social skills, fit within team and culture, } \\
\text { oral/written communication, common sense, openness to } \\
\text { change, problem solving }\end{array}$ \\
\hline \multirow{4}{*}{$\begin{array}{l}\text { Lim, Lee, } \\
\text { Yap, \& Ling } \\
* *((2016\end{array}$} & \multirow{4}{*}{ Malaysia } & \multirow{4}{*}{$\begin{array}{l}\text { Quantitative } \\
\text { ((Survey }\end{array}$} & Employers & $\begin{array}{l}\text { Oral/written communication, problem solving, analytical } \\
\text { skills and critical thinking, time management }\end{array}$ \\
\hline & & & Auditor & $\begin{array}{l}\text { Analytical skills, time management, pressure manage- } \\
\text { ment, team work, critical thinking }\end{array}$ \\
\hline & & & Lecturer & $\begin{array}{l}\text { Team work, analytical skills, pressure management, inter- } \\
\text { personal skills, oral/written communication }\end{array}$ \\
\hline & & & $\begin{array}{l}\text { Accounting } \\
\text { students }\end{array}$ & $\begin{array}{l}\text { Problom solving, team work, decision making, analytical } \\
\text { skills, pressure management }\end{array}$ \\
\hline \multirow{3}{*}{$\begin{array}{l}\text { Howcroft } \\
((2017\end{array}$} & \multirow{3}{*}{$\begin{array}{l}\text { UK and } \\
\text { Ireland }\end{array}$} & \multirow{3}{*}{$\begin{array}{l}\text { Quantitative } \\
\quad((\text { Survey } \\
\text { Qualitative } \\
\text { ((Interview }\end{array}$} & $\begin{array}{l}\text { Accounting } \\
\text { professional } \\
\text { body }\end{array}$ & Critical thinking, creative problem solving \\
\hline & & & Educators & $\begin{array}{l}\text { Problem solving, critical analysis, critical reading, techni- } \\
\text { cal knowledge }\end{array}$ \\
\hline & & & Employers & $\begin{array}{c}\text { Bookkeeping, verbal/ written communication and inter- } \\
\text { personal skills }\end{array}$ \\
\hline $\begin{array}{l}\text { Oussii \& } \\
\text { (Klibi }(2017\end{array}$ & Tunisian & $\begin{array}{l}\text { Quantitative } \\
\text { ((Survey }\end{array}$ & $\begin{array}{l}\text { Accounting } \\
\text { students }\end{array}$ & Verbal communication, interpersonal skills \\
\hline $\begin{array}{l}\text { Atanasovski, } \\
\text { Trpeska, \& }\end{array}$ & \multirow{2}{*}{$\begin{array}{l}\text { Macedo- } \\
\text { nia }\end{array}$} & \multirow{2}{*}{$\begin{array}{l}\text { Quantitative } \\
\text { ((Survey }\end{array}$} & Employers & $\begin{array}{c}\text { Computer-related skills, foreign language, ethical, } \\
\text { life-learning, credibility }\end{array}$ \\
\hline $\begin{array}{l}\text { Bozinovska } \\
\text { Lazarevska } \\
* *((2018\end{array}$ & & & $\begin{array}{l}\text { Accounting } \\
\text { students }\end{array}$ & $\begin{array}{l}\text { Problem solving, oral communication, foreign language, } \\
\text { personal characteristics, time management, team work }\end{array}$ \\
\hline
\end{tabular}

*Table 1 captures the selected studies which have used primary data. Studies have used job ads as a secondary data are discussed at the end of our introduction chapter.

** If there are lots of skills detected in the study, the most five importants are shown in the Table.

Table 1 shows that technical skills for accountants in the current business climate is still pertinent. However, an increasing need has arisen for accountants to develop soft skills. From 
a recent study, most of the key employers in the accounting sector in New Zealand believe that technical skills can be gained through "on the job training." They do not have much expectation that a new graduate would have the necessary core knowledge (Low et al., 2016). From a different perspective, Daff, De Lane and Jackling (2012) show that the current combination of soft and technical skills does not meet the expectations of several employers. Thus, they settle for a less stringent skill set. In summary, by repositioning the current accountants as knowledge professionals instead of accounting technicians, the required soft skills can be given more focus (Jones and Abraham, 2009). This leads us to our second research question:

RQ2: Do the employers' expected job skills of accounting graduates in Turkey differ from the literature's suggested skills?

The accounting profession is defined in the VQAAPS as follows: "The pre-accountancy employee (level 4) is a qualified person who carries out activities related to occupational health safety and environmental precautions. They write the working organization's pre-accountancy reports, prepare documents that are the basis for accounting, conduct things related to any papers needed, and handle the accounts pursuant to the relevant quality standards. " (Mesleki Yeterlilik Kurumu, 2015). This definition implies that technical skills are the only requirement for pre-accountants. However, to keep abreast of technological developments, besides economic and societal changes, pre-accountants in Turkey need to have soft skills as well (Demir, 2005). In addition, as Figure 1 illustrates, the VQAAPS includes the positioning of professions as well as information on how a professional profile should appear. Thus, we present our third research question, RQ3, to investigate whether the four sub-dimensions related to a professional profile agree with the pre-accounting job advertisements of the sector.

RQ3: Do the employers' expected job skills for the accounting profession in Turkey differ from those of the VQAAPS?

\section{Methodology}

Job advertisement (job ads) analysis is an unobtrusive approach to discover the competencies of jobs in different fields, such as librarians (Lopatovska and Baribeau, 2017), business managers (Bennett, 2002), and information system professionals (Todd, Mckeen, and Gallupe, 1995). Text analysis (TA) and content analysis (CA) are the most common methods to create meaningful texts from a dataset, including job advertisements. TA and CA are generally used interchangeably in the literature, although they have some key distinctions (Bauer, Bicquelet and Suerdem, 2014). Since we did not use abductive modeling techniques such as corpus linguistics, automatic pattern detection, and bottom-up categorization, we might say that we used text mining methods through TA via Wordstat. Restricting ourselves to within the scope of this study, we followed Chakraborty, Pagolu, and Garla's (2013) text-mining framework as shown in Figure 2. 
Data collection: We retrieved a total of 58,952 accounting job ads from an employment service platform in Turkey during the period 2008-2016. We considered only those job ads with the word "pre" in their job title, because, according to the VQAAPS, a level-4 accountant's basic priority should consist of pre-accounting tasks. Finally, we ended with 7,320 usable ads for further analysis.

Text parsing: In text parsing, also called the pre-processing phase, we used Ingersoll, Morton, and Farris's (2013) approach to transform our text and capture the patterns in textual data. Pre-processing is critically important for preparing a dataset for text mining. For this, we reduce the input text document size (Vijayarani and Janani, 2016), and then carry out the sub-processes, stop-word elimination, tokenization, stemming, and lemmatization. First, we obtain tokens by breaking the text into words. This is called tokenization. Second, we conduct stemming by removing the derivational suffixes. In addition, we group the inflected forms of a word to analyze them as a single item. This is called lemmatization, and is done to enable a morphological analysis of the words therein. Third, we create the excluded list for stop-word removal and conduct downcasing and synonym expansion.

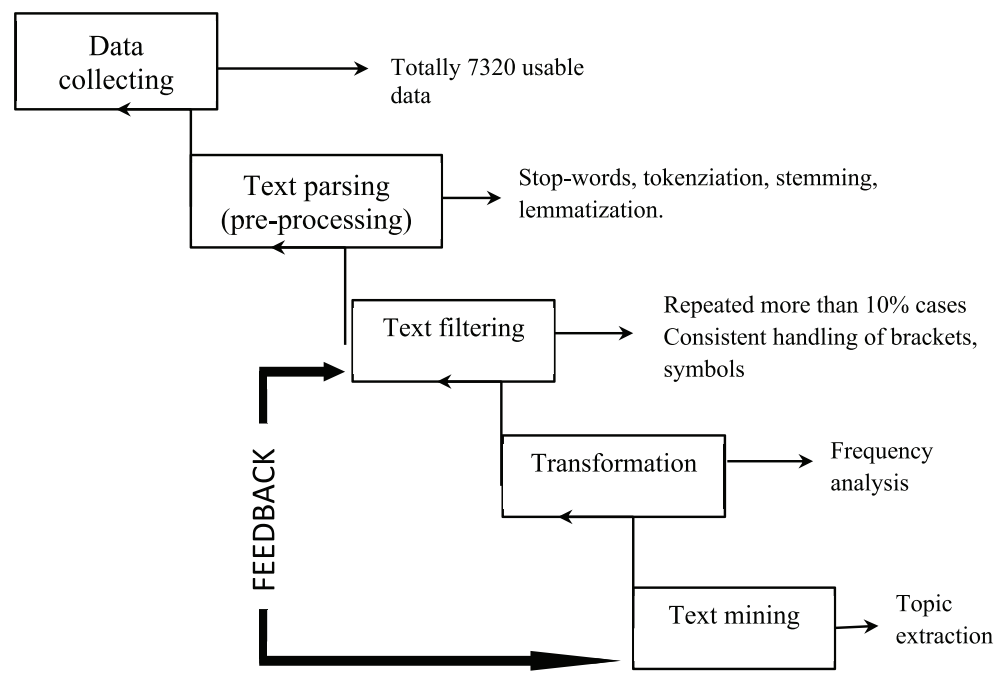

Figure 2. Text mining process (adapted from Chakraborty et al., 2013).

Text filtering: The brackets and symbols were adhered to consistently. Numeric characters were allowed since we filtered the job ads by year of publication. For better grasp and interpretation of the results, we filtered the frequencies in more than $10 \%$ of the cases.

Transformation: We calculated the frequency of job ads by year of publication and subtitles. We also investigated the frequency of words related to pre-accounting job skills.

Text mining: We used topic extraction based on job skills. 


\section{Results}

In this section, we first provided brief information on our corpus, and then presented our descriptive results, frequency, and topic extraction analysis.

\section{Corpus}

Table 2

Collection statistics

\begin{tabular}{lc}
\hline Total number of cases & 7320 \\
Total number of paragraphs & 44035 \\
Total number of sentences & 47842 \\
(Total number of words (token & 442442 \\
(Total number of word forms (type & 25916 \\
Total words excluded & 113812 \\
Words per sentence & 9,2 \\
Words per paragraph & 10 \\
\hline
\end{tabular}

\section{Descriptive Statistics}

Following the pre-processing stage, we examined the filtered ads by year of publication and sub-position. Table 3 presents the frequency table.

Table 3

Total Job Advertisements by Year and sub-position

\begin{tabular}{|c|c|c|c|c|c|c|c|c|c|c|c|}
\hline & 2008 & 2009 & 2010 & 2011 & 2012 & 2013 & 2014 & 2015 & 2016 & Total & Total Percent \\
\hline $\begin{array}{l}\text { Pre Accounting } \\
\text { Clerk }\end{array}$ & 81 & 101 & 210 & 272 & 445 & 678 & 731 & 525 & 363 & 3406 & $46,5 \%$ \\
\hline $\begin{array}{l}\text { Pre Accounting } \\
\text { Employee }\end{array}$ & 2 & - & - & & 2 & 24 & 24 & 26 & 13 & 91 & $1,2 \%$ \\
\hline $\begin{array}{l}\text { Pre Accounting } \\
\text { Personel }\end{array}$ & 5 & 7 & 18 & 18 & 42 & 127 & 113 & 120 & 98 & 548 & $7,5 \%$ \\
\hline Junior Accountant & 15 & 19 & 27 & 61 & 70 & 94 & 104 & 75 & 59 & 524 & $7,2 \%$ \\
\hline $\begin{array}{l}\text { Pre Accounting } \\
\text { Specialist }\end{array}$ & 4 & 5 & 8 & 9 & 10 & 23 & 14 & 17 & 22 & 112 & $1,5 \%$ \\
\hline $\begin{array}{l}\text { Pre Accounting } \\
\text { and Sale }\end{array}$ & & 5 & 21 & 28 & 34 & 41 & 34 & 29 & 28 & 220 & $3,0 \%$ \\
\hline $\begin{array}{l}\text { Pre Accounting } \\
\text { and Secretarial }\end{array}$ & 2 & 72 & 219 & 277 & 448 & 340 & 400 & 208 & 134 & 2100 & $28,7 \%$ \\
\hline Bookkeeper̃ & 3 & 9 & 5 & 11 & 13 & 27 & 42 & 82 & 127 & 319 & $4,4 \%$ \\
\hline TOTAL & 112 & 218 & 508 & 676 & 1064 & 1354 & 1462 & 1082 & 844 & 7320 & $100 \%$ \\
\hline
\end{tabular}

The most significant information in the frequency table is the variety of job titles. We expected more standardized job titles as per the VQAAPS (pre-accounting clerk). However, several hybrid versions existed. The VQAAPS prefers to use the "pre-accounting clerk" job title for level 4. Thus, our results are consistent with the standard; that is, high percentage of ads represented by "pre-accounting clerk." Table 3 shows a decreasing number of job ads 
after 2015. One possible reason is technological development in the accounting sector, such as the use of e-invoices (Elçin et al., 2018). However, Table 3 may be misleading. A more detailed interpretation is required. As previously mentioned, the VQAAPS was released in late 2015. A careful examination of the trends of sub-positions surprisingly shows that after 2015, job ads for the pre-accounting clerical job decreased, whereas those for bookkeeper jobs increased. This result is disappointing for two reasons.

First, vocational standards need to lead the sector and bridge the gap between employees and employers. From our results, the VQAAPS seems to have failed in this since the number of pre-accounting clerical job titles mentioned actually decreased. This is not as expected after the release of standards. Second, calling a level-4 accountant bookkeeper is not acceptable for linguistic reasons. The Turkish translation of the word "bookkeeper" is "muhasebeci." When the suffix "ci" is added to the root word of a profession name in Turkish to indicate the reputation of the profession, the reputation of the profession "falls from grace." For example, the profession of dentistry can be expressed in two different ways in Turkish. You can call it disci, derived from the root word of the profession dis (tooth) and the suffix "ci." You can also directly name the profession dis doktoru (tooth doctor) in Turkish. Professional dentists prefer to be called "tooth doctor" because the other term is likely to underestimate the professional's job. When we associate this situation with the accounting profession "bookkeeper," the Turkish term muhasebeci has the suffix "ci" at the end of the profession. This discredits the job's reputation. After 2015, the bookkeeper job title has undergone rapid change, contrary to the VQAAPS standard. Although we considered only the 2016 data for this interpretation, these trends provide some evidence that the accounting sector does not follow, or even ignores, the national standards.

After representation of the general structure, we analyzed the job ads by the job description and job skills separately since these two aspects have different meanings and purposes. Job descriptions capture the general tasks, job-related duties, and responsibilities of the position with regard to the employees' technical skills, whereas job skills are mostly related to the desired individual employee characteristics, such as their analytical and time management skills, both of which can be called soft skills.

\section{Job Skills Analysis}

Table 4 gives a summary of the frequency of words related to job skills. The number of times a word has been repeated in the job skills section is shown in the "frequency" column, while the number of cases with related features is shown in the "number of cases" column.

Table 4

Word Frequencies in reference to Job Preferences

\begin{tabular}{lcccc}
\hline Word & Number of cases & Cases \% & Frequency & Shown \% \\
\hline Female & 2714 & $37.08 \%$ & 2772 & $2.30 \%$ \\
Graduation & 2421 & $33.07 \%$ & 2616 & $2.17 \%$ \\
MSOffice & 2047 & $27.96 \%$ & 2057 & $1.71 \%$ \\
\hline
\end{tabular}




\begin{tabular}{lcccc}
\hline Word & Number of cases & Cases \% & Frequency & Shown \% \\
\hline Experienced & 1896 & $25.90 \%$ & 2059 & $1.71 \%$ \\
Decent & 1334 & $18.22 \%$ & 1359 & $1.13 \%$ \\
High school & 1328 & $18.14 \%$ & 1343 & $1.12 \%$ \\
Diction & 1273 & $17.39 \%$ & 1278 & $1.06 \%$ \\
LOGO & 994 & $13.58 \%$ & 1027 & $0.85 \%$ \\
Communication & 966 & $13.20 \%$ & 1014 & $0.84 \%$ \\
Responsibility & 796 & $10.87 \%$ & 813 & $0.68 \%$ \\
Male & 767 & $10.48 \%$ & 792 & $0.66 \%$ \\
Team & 749 & $10.23 \%$ & 796 & $0.66 \%$ \\
Age & 744 & $10.16 \%$ & 752 & $0.62 \%$ \\
\hline *We chose the words which were repeated in more than $10 \%$ of the cases. & &
\end{tabular}

Following the word frequency analysis, we analyzed the job skills by their respective topics. The results are presented in Table 5.

The job skills that employers expect for candidates can be grouped under two main headings following the CPA Australia's categorization (CPA Australia): technical skills and soft skills. As discussed in the literature review section, in addition to technical skills, certain skills are required to effectively apply the technical skills - soft skills. The table above clearly shows that employers expect their candidates to be more competent with regard to professional/technical knowledge, indicating their focus on the so-called technical skills rather than soft skills. Although the detected soft skills are slightly more than the technical skills in number (seven versus six), considering the frequency of times and number of cases that these concepts appeared, the dominance of technical skills is clearly evident.

From the candidates' educational level (e.g., university, high school, or vocational school), people with higher education seem to be preferred. In Turkey, you do not need a bachelor's degree to apply for pre-accounting positions. Two-year vocational college students can be considered for pre-accounting positions (Allahverdi and Karaer, 2019). This finding shows the dichotomy of pre-accounting employees in Turkey. Specifically, the question of whether a pre-accounting employee can be considered a professional or as holding an occupation arises. Although numerous studies have made a distinction between an occupation and profession (Chitty, 1997), the consensus is that long-term education is indispensable for the required level of professionalism. In line with this thinking, a pre-accounting staff finishing vocational school cannot be considered as holding the required standards of professionalism. Thus, in Turkey, it is more appropriate to consider a pre-accountant job as holding an occupation. However, a pre-accounting position can later come to be regarded as a professional job, such as when the secretarial job titles decreased and specialist job titles increased slightly from 2013 to 2016 (Table 3). 
Table 5

Topic Frequencies in relation to Job Preferences

\begin{tabular}{|c|c|c|c|c|c|}
\hline & Topic & Keywords & $\begin{array}{l}\text { Number of } \\
\text { cases }\end{array}$ & Cases \% & Frequency \\
\hline \multirow{6}{*}{$\begin{array}{l}\text { TECH- } \\
\text { NICAL } \\
\text { SKILLS }\end{array}$} & $\begin{array}{l}\text { Basic accounting } \\
\text { knowledge }\end{array}$ & $\begin{array}{l}\text { Invoice; current account; bank; } \\
\text { bond; inventory; payment; daily } \\
\text { cash; tax; agreement }\end{array}$ & 4884 & $66.72 \%$ & 7731 \\
\hline & MSOffice & Word; excel; very well & 4008 & $54.75 \%$ & 7102 \\
\hline & $\begin{array}{l}\text { Graduation } \\
\text { degree }\end{array}$ & $\begin{array}{l}\text { High school; trade vocational; } \\
\text { university; bachelor; vocational } \\
\text { school of higher education; } \\
\text {;business; public finance } \\
\text { economics }\end{array}$ & 3514 & $48.01 \%$ & 8154 \\
\hline & $\begin{array}{l}\text { Real life } \\
\text { experience }\end{array}$ & $\begin{array}{l}\text { Year; minimum; experience; } \\
\text { similar position }\end{array}$ & 2881 & $39.35 \%$ & 3627 \\
\hline & $\begin{array}{l}\text { Vocational soft- } \\
\text { ware knowledge }\end{array}$ & ;LOGO; Tiger; program & 2509 & $34.28 \%$ & 1754 \\
\hline & Secretarial tasks & $\begin{array}{c}\text {;Telephone; fax traffic } \\
\text { photocopy; e-mail; cargo }\end{array}$ & 1869 & $25.53 \%$ & 1342 \\
\hline \multirow{7}{*}{$\begin{array}{l}\text { SOFT } \\
\text { SKILLS }\end{array}$} & $\begin{array}{l}\text { Verbal/ written } \\
\text { communication }\end{array}$ & $\begin{array}{l}\text {;Diction; decent } \\
\text { representational skills }\end{array}$ & 2796 & $38.20 \%$ & 2897 \\
\hline & Problem solving & $\begin{array}{c}\text { Planning; analytic; organizing; } \\
\text { coordination; concentrate; } \\
\text { attentive; solution-oriented; } \\
\text { pursuer }\end{array}$ & 2726 & $37.24 \%$ & 4211 \\
\hline & $\begin{array}{c}\text { Time } \\
\text { management }\end{array}$ & $\begin{array}{c}\text {;Flexible working hours } \\
\text {;dynamic environment } \\
\text { compatible }\end{array}$ & 2363 & $32.28 \%$ & 5784 \\
\hline & Presentable & $\begin{array}{c}\text { Debonair; personal care; outer } \\
\text { view; elegant }\end{array}$ & 1910 & $26.9 \%$ & 2173 \\
\hline & $\begin{array}{l}\text { Professional } \\
\text { demeanor }\end{array}$ & $\begin{array}{l}\text { Principled; responsible; orga- } \\
\text { nized; attentive; elaborative }\end{array}$ & 1611 & $22.01 \%$ & 1341 \\
\hline & $\begin{array}{l}\text { Interpersonal } \\
\text { skills }\end{array}$ & $\begin{array}{l}\text { Human relations; successful; } \\
\text { debonair }\end{array}$ & 1455 & $19.88 \%$ & 1703 \\
\hline & Self-confidence & Responsibility; open-minded & 1446 & $19.75 \%$ & 940 \\
\hline
\end{tabular}

\section{Comparison and Summary of Results}

From our results, of the 25 criteria, only 12 have been commonly identified in the literature, standards, and the sector. These criteria are as follows: graduation with a degree; a professional demeanor; core accounting knowledge; and technological, written and verbal communication, decision-making, teamwork, problem-solving, documentation, computing, resource and time management, and planning skills. We believe that anyone wanting to work in the pre-accounting field in Turkey should have these capabilities. As regards the requirements of the sector in Turkey, in addition to these criteria, the candidate needs to be presentable. Initiative, professionalism, and lifelong learning also appear in both the literature and standards, although the sector does not consider these attributes important. This implies that 
the sector does not look for individuals who are willing to learn continuously, improve themselves, and perform innovatively. However, good looks seem to be indispensable for working in the accounting field. One reason for this could be that those holding pre-accounting and secretarial jobs are responsible for welcoming guests. This appears to be one of the most common factors with a $28.7 \%$ frequency, as shown in Table 3. Ethical issues have unfortunately been neglected. Since the most famous scandals in the accounting area in Turkey are due to unethical behavior (Dellaportas, 2006; Esmond-Kiger, 2004; Koumbiadis and Okpara, 2008), the sector's attitude to this issue calls for an in-depth investigation.

Table 6

Comparison of VQAPP, the literature and the industry criteria according to pre-accountant job preferences

\begin{tabular}{|c|c|c|c|}
\hline THE CRITERIA & LITERATURE & STANDARD & SECTOR \\
\hline Professional demeanour & $\checkmark$ & $\checkmark$ & $\checkmark$ \\
\hline Core Accounting Knowledge & $\checkmark$ & $\checkmark$ & $\checkmark$ \\
\hline Technological Skills & $\checkmark$ & $\checkmark$ & $\checkmark$ \\
\hline Written \& verbal communication & $\checkmark$ & $\checkmark$ & $\checkmark$ \\
\hline Analytical and critical thinking & $\checkmark$ & $\mathrm{X}$ & $\mathrm{X}$ \\
\hline Foreign language & $\checkmark$ & $\mathrm{X}$ & $\mathrm{X}$ \\
\hline Lifelong learning & $\checkmark$ & $\checkmark$ & $\mathrm{X}$ \\
\hline Real life experience & $\checkmark$ & $\mathrm{X}$ & $\checkmark$ \\
\hline Decision-making & $\checkmark$ & $\checkmark$ & $\checkmark$ \\
\hline Pressure management & $\checkmark$ & $\mathrm{X}$ & $\checkmark$ \\
\hline Leadership & $\checkmark$ & $\mathrm{X}$ & $\mathrm{X}$ \\
\hline Teamwork skills & $\checkmark$ & $\checkmark$ & $\checkmark$ \\
\hline Self-confidence & $\checkmark$ & $\mathrm{X}$ & $\checkmark$ \\
\hline Intellectual abilities & $\checkmark$ & $\mathrm{X}$ & $\mathrm{X}$ \\
\hline Problem-solving & $\checkmark$ & $\checkmark$ & $\checkmark$ \\
\hline Emergency management & $\mathrm{X}$ & $\checkmark$ & $\mathrm{X}$ \\
\hline Occupational health and safety Knowledge & $\mathrm{X}$ & $\checkmark$ & $\mathrm{X}$ \\
\hline Documentation & $\checkmark$ & $\checkmark$ & $\checkmark$ \\
\hline Computing Techniques & $\checkmark$ & $\checkmark$ & $\checkmark$ \\
\hline Initiative and enterprise & $\checkmark$ & $\checkmark$ & $\mathrm{X}$ \\
\hline Graduation degree & $\checkmark$ & $\checkmark$ & $\checkmark$ \\
\hline Resource and time management & $\checkmark$ & $\checkmark$ & $\checkmark$ \\
\hline Planning & $\checkmark$ & $\checkmark$ & $\checkmark$ \\
\hline Ethic/Credibility & $\checkmark$ & $\checkmark$ & $\mathrm{X}$ \\
\hline Presentable & $\mathrm{X}$ & $\mathrm{X}$ & $\checkmark$ \\
\hline
\end{tabular}

Analytical and critical thinking, leadership and intellectual abilities, and foreign language knowledge do not seem to be consistently required skills in Turkey (standard and sector requirements) and the literature. For the first two, accounting processes generally consist of national rules and routine work orders, and these attributes do not count much and are not considered worth gaining by Turkish pre-accountants. Furthermore, one recent study provides evidence that employers consider knowledge of a foreign language the least important skill for accounting graduates (Coşkun et al.2017). 
The literature and the Turkish sector concur in terms of the three attributes of real-life experience, pressure management, and self-confidence. In Turkey, a pre-accountant position is simply a starting point to an accounting career; this explains why the standard does not demand real-life experience for this position. Although a recent study has indicated selfconfidence and pressure management as important skills from the perspective of an auditor, lecturer, or student (Lim et al., 2016), the VQAAPS fails to mention these competencies.

Emergency management and occupational health and safety knowledge appear only within the scope of local standards. This is a legal obligation for any occupational standard by definition. As a general assessment, local standards and the sector share much in common with the international literature. This finding is surprising because the VQAAPS was established by a professional accounting association called the Union of Chambers of Certified Public Accountants and the Sworn-In Certified Public Accountants of Turkey (TURMOB). Thus, the standards and sector should be more similar. This discrepancy may be due to the insufficient and/or non-elaborate workforce analysis conducted before establishing the standards.

\section{Conclusions}

Before discussing our research questions in detail, we first evaluated the results in general. Overall, a graduation degree, general accounting, and MS Office knowledge are the most sought-after technical skills. Furthermore, time management, problem solving, and communication skills are the most desired soft skills. Although the detected number of soft skills is slightly higher than that of technical skills (seven versus six), given the frequency and higher number of cases in which these attributes appeared, the prevalence of technical skills can be clearly accepted. The dominance of technical skills contradicts Tan and Laswad's (2018) findings that interpersonal and personal skills are the most sought-after skills by employers in Australasia. The main reason for this difference is that an accounting position is perceived as an occupation rather than profession in Turkey, whereas accountants are considered business professionals rather than "backroom number crunchers" in the Australasian countries. Nevertheless, it is a mistake to underestimate routine skills, such as IT and core accounting knowledge, especially for entry-level accountants (Liyan, 2013; Tan and Laswad, 2018), even though some scholars believe that technical skills can be gained through "on the job training" (Low et al., 2016).

One remarkable finding is that the most required specification for a potential preaccounting staff was that the applicant should be female. This interesting finding contradicts previous research since the majority of accounting-related studies have claimed that accounting is a liberal profession dominated by men in most countries (Del Baldo, Tiron-Tudor, and Faragalla, 2018). However, this situation may vary owing to cultural differences (Wells and Fieger, 2006; Kyriakidou et al., 2016) and the fact that an increasing percentage of women 
have started to have a voice in the accounting sector after the 1970s (Walker, 2008). Two plausible reasons can be given for this unexpected finding. First, as Bryant (2010) has suggested, a woman's career advancement in accounting is more difficult than that of a man. Women are more likely to be positioned at a lower level. The reason for requiring female candidates could be that this study focused on the entry-level accounting job title, pre-accountancy. This argument is supported by other studies that claim that women have a low rate of participation in higher-level accounting positions (Keiran, 2017; Del Baldo et al., 2018), and that more women have a lower job status than men (Whiting and Wright, 2001). Similarly, a recent study has shown the predominance of male accountants in large businesses and female accountants in small and medium enterprises (Silva, Dal Magro, Gorla, and Silva, 2018). The second reason is that the majority of job ads consisted of pre-accounting clerical and secretarial sub-positions. Women seem to be considered more suitable for these positions. This claim is similar to the findings of Riach and Rich (2006) that $97 \%$ of the people in secretarial positions are women. The third reason relates to Turkish cultural norms, where women exemplify femininity rather than independence. Thus, in Turkey, women's tasks are generally associated with their homes (Akın, 2017). Women tend to be hired more in secretarial positions because these tasks can be considered "housework" in the context of companies. In response to Booth and Leigh's (2010) findings of gender-stereotyping of job demands, we argue that in Turkey, when looking for pre-accountants, the sector prefers females. Nevertheless, considering gender equality, we have to state that "being female" cannot be considered a job skill criterion.

Another interesting finding is the lack of consensus on the qualification required to apply for a pre-accounting job in Turkey. Scholars indicate that a profession is different from an occupation in that it requires long-term education and orientation processes (Chitty, 1997). We can thus assert that a confusion exists on whether the sector perceives an accounting field job as a profession or as an occupation.

This study proposes that core pre-accounting competencies come from three different perspectives, the sector, standards, and the literature; our results show both similarities and differences between them. For the first research question, 16 criteria appear to be what the Turkish sector required for pre-accounting employees. As regards the second research question, we plausibly assert that the pre-accountants' job skills required by the Turkish sector are similar to those required in the literature; more than half of the 25 job skills pertain to the soft skills identified in both the sector and the literature. The difference of only seven out of the twenty-five criteria between the sector and the literature signifies consistency in their requirements.

In contrast with Tsui's (2013) findings, the gap between the sector and academia in Turkey seems to be reasonable. However, with regard to our third research question, the gap between the sector and standards across the nine criteria reveals that the VQAAPS' standards are less compatible with the sector's expectations than in the literature. In the same line, eight diffe- 
rent pre-accountant sub-job titles in the ILO can be considered a universal initiator. This is similar to our results (Table 3). However, the VQAAPS suffers from its job title positioning. These results prove that the Turkish sector is more adapted to international criteria than the local standards.

Finally, the results show that although the local standards follow the ILO and TURMOB guidance, gaps actually do exist, especially between the sector and local standards. This is very important because all countries' local standards generally follow the ILO framework. Although the TURMOB has been consulted, such consultation is insufficient to reflect the sector's real expectations. As a general recommendation, we suggest that policymakers pay attention to the employers' opinions before establishing national standards.

\section{Limitations and further studies}

Despite its valuable contributions and the relative paucity of this type of research in the accounting area, this study has some limitations. The first limitation is that our data relate to only Turkey. More comparative studies involving data from different countries need to follow. Second, the data cover nine years only. If more comprehensive data could be gathered, longitudinal studies could be conducted to highlight the changing trends in the accounting field and achieve more generalizable results. Third, we considered only job skills. However, there are job descriptions in the job ads that could be further analyzed. Fourth, we used only $12 \%$ of our data since we focused only on "pre" accountant (entry-level) job ads, although there are other job titles such as accounting manager and accounting director, which are considered to be more senior positions with more responsibilities. Therefore, their corresponding job skills may differ from our results.

Author Contributions: Conception/Design of study: T.K., B.K. A.A.; Data Acquisition: A.A.; Data Analysis/Interpretation: T.K., B.K. A.A.; Drafting Manuscript: T.K., B.K. A.A.; Critical Revision of Manuscript: A.A.; Final Approval and Accountability: T.K., B.K. A.A.

\section{References}

Abayadeera, N. and Watty, K. (2014) 'The expectation-performance gap in generic skills in accounting graduates: Evidence from Sri Lanka', Asian Review of Accounting, 22(1), pp. 56-72.

Ahmad, N. S. and Gao, S. S. (2004) 'Changes, problems and challenges of accounting education in Libya', Accounting Education, 13(3), pp. 365-390. doi: 10.1080/0963928042000273825.

Akın, Ü. (2017) 'Türk Toplumunda Aile ve Kadının Ailedeki Konumu', in Elmas, N. (ed.) Kadın ve Aile 
Hayatı. Ankara: Pegem Akademi, pp. 35-56.

Albrecht, W. \& Sack, R., 2000. Accounting education: Charting the course through a perilous future, Sarasota: Accounting Education Series.

Ali, I. M. et al. (2016) 'Perception of Employers and Educators in Accounting Education', Procedia Economics and Finance, 35(16), pp. 54-63. doi: 10.1016/S2212-5671(16)00009-5.

Allahverdi, M. and Karaer, M. (2019) 'The Effects of E-Transformation on Accounting Profession Qualifications and Analaysis of Undergraduate Level Accounting Education in Turkey in terms of Vocational Competencies', Muhasebe Bilim Dünyası Dergisi, 21(1), pp. 246-273.

Atagan Çetin, A. (2017) 'İşletme Bölümü Öğrencilerinin Muhasebe Mesleği ve Muhasebe Eğitimi Algısının 2006 ve 2016 Yıllarındaki Değişimin Karşılaştırılması', Mesleki Bilimler Dergisi, 6(2), pp. 240-251.

Atanasovski, A., Trpeska, M. and Bozinovska Lazarevska, Z. (2018) 'Accounting Students' and Employers' Perceptions on Employability Skills in the SEE Country', European Financial and Accounting Journal, 2018(3), pp. 55-72. doi: 10.18267/j.efaj.214.

Augier, M. \& March, J., (2007). The pursuit of relevance in management education. California Management Review, 49(3), pp. 129-146.

Awayiga, J. Y., Onumah, J. M. and Tsamenyi, M. (2010) 'Developing-Knowledge and skills development of accounting graduates: The perceptions of graduates and employers in Ghana', Accounting Education, 19(1-2), pp. 139-158. doi: 10.1080/09639280902903523.

Bancino, R. \& Zevalkink, C., 2007. Soft skills: the new curriculum for hard-core technical professionals. Techniques: Connecting Education and Careers, 85(2), pp. 20-22.

Başar, A. B. (2005) 'Skills for Success in the Accounting Profession and Changing Face of Accounting Education', Dumlupinar University Journal of Social Sciences, (13).

Bauer, M. W., Bicquelet, A. and Suerdem, A. K. (2014) Text Analysis: An Introductory Manifesto, Textual Analysis. Sage Benchmarks in Social Research Methods. Available at: http://eprints.lse.ac.uk/57383/.

Bayerlein, L. and Timpson, M. (2017) 'Do accredited undergraduate accounting programmes in Australia meet the needs and expectations of the accounting profession?', Education and Training, 59(3), pp. 305-322. doi: 10.1108/ET-04-2016-0074.

Bennett, R. (2002) 'Employers' demands for personal transferable skills in graduates: A content analysis of 1000 job advertisements and an associated empirical study', Journal of Vocational Education and Training, 54(4), pp. 457-476. doi: 10.1080/13636820200200209.

Bennis, W. G. and O'Toole, J. (2005) 'How business schools lost their way', Harvard Business Review, 83(5), pp. 98-104.

Booth, A. and Leigh, A. (2010) 'Do employers discriminate by gender? A field experiment in female-dominated occupations', Economics Letters. Elsevier B.V., 107(2), pp. 236-238. doi: 10.1016/j.econlet.2010.01.034.

Bryant, L. L. (2010) 'What role does the "Glass ceiling” play for women in the accounting?', The York Scholar, 1, pp. 2-13.

Bui, B. and Porter, B. (2010) 'The expectation-performance gap in accounting education: An exploratory study’, Accounting Education, 19(1-2), pp. 23-50. doi: 10.1080/09639280902875556.

Chakraborty, G., Pagolu, M. \& Garla, S., (2013). TM and Analysis: Practica lMethods, Examples, and Case Studies Using SAS. USA: SAS Institute Inc.. 
Chitty, K. (1997) Professional Nursing. Philadelphia: Saunders Company.

Coetzee, S. \& Oberholzer, R., (2009). The tax knowledge of South African trainee accountants: a survey of the perceptions of training officers in public practice. Accounting Education, 18(4), pp. 421-441.

Coşkun, S., Kır, A. and Coşkun, S. (2017) 'A research on Evaluation of Business World's Expectations From Accounting Education', International Journal of Management Economics and Business, Special Is, pp. 330-341.

CPAAustralia (2019) International Accreditation Guidelines: Assuring Accounting Education Quality, Section 3: Professional Skills, Competence Areas and Learning Outcomes. Available at: https://www.cpaaustralia.com.au/academics/accreditation-guidelines-for-higher-education-programs/international-accreditation-guidelines/section-3-professional-skills-competence-areas-and-learning-outcomes.

Crawford, L., Helliar, C. and Monk, E. A. (2011) 'Generic skills in audit education', Accounting Education, 20(2), pp. 115-131. doi: 10.1080/09639284.2011.557487.

Daff, L., De Lange, P. and Jackling, B. (2012) 'A Comparison of Generic Skills and Emotional Intelligence in Accounting Education', Issues in Accounting Education, 27(3), pp. 627-645. Available at: https://www. researchgate.net/publication/275944771_A_Comparison_of_Generic_Skills_and_Emotional_Intelligence_in_Accounting_Education/references.

Del Baldo, M., Tiron-Tudor, A. and Faragalla, W. (2018) 'Women's Role in the Accounting Profession: A Comparative Study between Italy and Romania', Administrative Sciences, 9(1), p. 2. doi: 10.3390/admsci9010002.

De Lange, P., Jackling, B. and Gut, A. M. (2006) 'Accounting graduates' perceptions of skills emphasis in undergraduate courses: An investigation from two victorian universities', Accounting and Finance, 46(3), pp. 365-386. doi: 10.1111/j.1467-629X.2006.00173.x.

Dellaportas, S., (2006). Making a difference with a discrete course on accounting. Journal of Business Ethics, 65(4), pp. 391-404.

Demir, B. (2005) ‘Üniversitede Kazanılan İletişim Becerilerinin Muhasebe Mesleğindeki Önemi’, Muhasebe ve Finansman Dergisi, 27, pp. 117-124.

Dunbar, K., Laing, G. and Wynder, M. (2016) 'A Content Analysis of Accounting Job Advertisements: Skill Requirements for Graduates', e-Journal of Business Education and Scholarship Teaching, 10(1), p. 58.

Elçin, R., Gerekan, B. and Usta, M. (2018) 'Problems Encountered During the Transition Process to E-Invoice, E-Books, and E-Archieve Applications: A Study on Certified Public Accountants', Mali Çözüm, 2(146), pp. 13-42.

Esmond-Kiger, C., (2004). Making ethics a pervasive component of accounting. Management Accounting Quarterly, 5(4), pp. 42-52.

France, A. (2010) 'Management accounting practices reflected in job advertisements', Journal of New Business Ideas \& Trends, 8(2), pp. 41-57.

Hancock, P. , Freeman, M., Watty, K., Birt, J., Tyler, J.(2016) Accounting Learning Standards, AFAANZ. Melbourne, Australia. Available at: https://www.afaanz.org/sites/default/files/uploaded-content/websitecontent/new-teaching-and-learning-standards-final-2016_1.pdf.

Hancock, P., Howieson, B. and Kent, J. (2009) Accounting for the future : more than numbers. Final report.

Howcroft, D. (2017) 'Graduates' vocational skills for the management accountancy profession: exploring the accounting education expectation-performance gap', Accounting Education. Taylor \& Francis, 26(5-6), pp. 459-481. doi: 10.1080/09639284.2017.1361846. 
Hughes, T., O'Regan, N. and Wornham, D. (2008) 'The credibility issue: closing the academic/practitioner gap', Strategic Change, 17(7-8), pp. 215-233. doi: 10.1002/jsc.828.

IFAC, 2003. Framework for International Education Statements, s.1.: s.n.

Ingersoll, G., Morton, T. \& Farris, A., 2013. Taming Text: How to Find, Organize, and Manipulate it. New York: Manning Publications and Co..

International Labour Organization, 2016. ISCO-08 Part 1: Introductory and methodological notes. Available at: http://www.ilo.org/public/english/bureau/stat/isco/docs/methodology08.docx

International Labour Organization (ILO), 2019. International Labour Organization (ILO). Available at: https://www.ilo.org/global/about-the-ilo/lang--en/index.htm

Jackling, B. and De Lange, P. (2009) 'Do accounting graduates' skills meet the expectations of employers? a matter of convergence or divergence', Accounting Education, 18(4-5), pp. 369-385. doi: $10.1080 / 09639280902719341$.

Jackling, B. and Watty, K. (2010) 'Generic skills', Accounting Education, 19(1-2), pp. 1-3. doi: $10.1080 / 09639280902875549$.

Jones, C. G. (2011) 'Written and computer-mediated accounting communication skills: An employer perspective', Business Communication Quarterly, 74(3), pp. 247-271. doi: 10.1177/1080569911413808.

Jones, G. and Abraham, A. (2009) 'The Value of Incorporating Emotional Intelligence Skills in the Education of Accounting Students.', Australasian Accounting Business \& Finance Journal, 3(2), pp. 48-60. doi: http://dx.doi.org/10.1108/17506200710779521.

Jones, R. (2014) 'Bridging the Gap: Engaging in Scholarship with Accountancy Employers to Enhance Understanding of Skills Development and Employability', Accounting Education. Taylor \& Francis, 23(6), pp. 527-541. doi: 10.1080/09639284.2014.965959.

Kaplan, R. S. (2011) 'Accounting scholarship that advances professional knowledge and practice', Accounting Review, 86(2), pp. 367-383. doi: 10.2308/accr.00000031.

Kavanagh, M. H. and Drennan, L. (2008) 'What skills and attributes does an accounting graduate need? Evidence from student perceptions and employer expectations', Accounting and Finance, 48(2), pp. 279300. doi: 10.1111/j.1467-629X.2007.00245.x.

Keiran, S. E. (2017) 'Gender Roles in Public Accounting and the Absence of Women in Upper Level Management’, pp. 1-49. Available at: http://scholars.unh.edu/honors/358.

Kenny, S. Y. and Larson, R. K. (2018) 'A review and analysis of Advances in International Accounting research', Journal of International Accounting, Auditing and Taxation. Elsevier, 30(March), pp. 117-126. doi: 10.1016/j.intaccaudtax.2018.03.001.

Kim, T., Ghosh, B. \& Meng, L., 1993. Selection criteria: perception gap between employers and accounting graduates. Singapore Accountant, Cilt 9, pp. 32-33.

Koumbiadis, N. and Okpara, J. O. (2008) 'Ethics and Accounting Profession : An Exploratory Study of Accounting Students in Post Secondary Institutions', International Review of Business Research Papers, 4(5), pp. 147-156.

Kyriakidou, O., Kyriacou, O., Özbilgin, M.F., \& Dedoulis, E. (2016). Editorial: Equality, diversity and inclusion in accounting. Critical Perspectives on Accounting, 35, 1-12. (2016) 'Editorial: Equality, diversity and inclusion in accounting', Critical Perspectives on Accounting, 35, pp. 1-12. doi: 10.1016/j. cpa.2015.12.004.

Lim, Y. M., Heang Lee, T., Yap, C.S. and Ling, C.C., (2016) 'Employability skills, personal qualities, 
and early employment problems of entry-level auditors: Perspectives from employers, lecturers, auditors, and students', Journal of Education for Business. Taylor \& Francis, 91(4), pp. 185-192. doi: 10.1080/08832323.2016.1153998.

Lin, Z. J. (2008) 'A factor analysis on knowledge and skill components of accounting education: Chinese case', Advances in Accounting, 24(1), pp. 110-118. doi: 10.1016/j.adiac.2008.05.009.

Lin, Z. J., Xiong, X. and Liu, M. (2005) 'Knowledge base and skill development in accounting education: Evidence from China', Journal of Accounting Education, 23(3), pp. 149-169. doi: 10.1016/j.jaccedu.2005.06.003.

Liyan, L. (2013) 'The impact of information technology on accounting theory, accounting profession, and Chinese Accounting education', in WHICEB Proceedings, p. 103.

Lopatovska, I. and Baribeau, H. (2017) 'What information professionals need to know: Job ads analysis', Proceedings of the Association for Information Science and Technology, 54(1), pp. 747-749. doi: 10.1002/pra2.2017.14505401141.

Low, M., Botes, V., Rue, D. \& Allen, J., 2016. Accounting employers' expectations - the ideal accounting graduates. E-Journal of Business Education \& Scholarship of Teaching, 10(1), p. 36.

Marshall, P., Dombroski, R., Garner, R. \& Smith, K., 2010. The accounting education gap. CPA Journal, 80(6), pp. 6-10.

McMurray, S., Dutton, M., McQuaid, R. \& Richard, A., 2016. Employer demands from business graduates. Education + Training, 58(1), pp. 112-132.

Mesleki Yeterlilik Kurumu, 2015. Ulusal Meslek Standardl-Ön Muhasebe Elemanı-Seviye 4. Available at: file://C:/Users/aidata/Downloads/15UMS0505-4\%20Rev\%2000\%20\%C3\%96n\%20Muhasebe $\% 20$ Eleman $\%$ C4\%B1\%20(2).pdf

Millard, P., 2003. Promoting the profession. Chartered Accountant Journal of New Zealand, 82(1), p. 13.

Mohamed, E. K. A. and Lashine, S. H. (2003) 'Accounting Knowledge and Skills and the Challenges of A Global Business Environment’, Managerial Finance, 29(7), pp. 3-16.

Morgan, G. J. (1997) 'Communication skills required by accounting graduates: practitioner and academic perceptions', Accounting Education, 6(2), pp. 93-107. doi: 10.1080/096392897331514.

Norain, S., Abdul Latiff, A. R. and Mohd Said, R. (2018) 'Employers "Perception on Skill Competencies and the Actual Performance of Bachelor of Accounting Graduates in Malaysia', International Academic Journal of Accounting and Financial Management, 5(3), pp. 88-95.

Oussii, A. A. and Klibi, M. F. (2017) 'Accounting students' perceptions of important business communication skills for career success: An exploratory study in the Tunisian context', Journal of Financial Reporting and Accounting, 15(2), pp. 208-225.

Paguio, R. and Jackling, B. (2016) 'Teamwork from accounting graduates: what do employers really expect', Accounting Research Journal, 29(3), pp. 348-366.

Rebele, J. E. and St. Pierre, E. K. (2015) 'Stagnation in accounting education research', Journal of Accounting Education. Elsevier Ltd, 33(2), pp. 128-137. doi: 10.1016/j.jaccedu.2015.04.003.

Riach, P. \& Rich, J., 2006. An experimental investigation of sexual discrimination in hiring in the English labor market. BE Press Advances in Economic Analysis \& Policy, 6(2), p. Article 1.

Şengel, S. (2011) 'Türkiye'de Muhasebe Meslek Elemanı Talebi Üzerine Bir Araştırma', Muhasebe ve Finansman Dergisi, (Nisan), pp. 167-180. Available at: http://journal.mufad.org.tr/attachments/article/483/9.pdf. 
Shankar, V., Venkatesh, A., Hofacker, C. \& Naik, P., 2010. Mobile Marketing in the Retailing Environment: Current Insights and Future Research Avenues. Journal of Interactive Marketing, 24(2), pp. 111-120.

Silva, J. C., Baú Dal Magro, C., Gorla, M.C. and da Silva M.Z. (2018) 'Glass ceiling in the accounting profession: Evidence in Brazilian companies’, Contaduría y Administración, 63(2), p. 16. doi: 10.22201/ fca.24488410e.2018.928.

Simons, K. \& Higgins, M., 1993. An examination of practitioners' and academicians' views on the content of the accounting curriculum. Accounting Educators' Journal, 8(2), pp. 24-34.

Stone, G., Lightbody, M. \& Whait, R., 2013. Developing accounting students' listening skills: barriers, opportunities and an integrated stakeholder approach. Accounting Education, 22(2), pp. 168-192.

Tan, L. M. and Laswad, F. (2018) 'Professional skills required of accountants: what do job advertisements tell us?', Accounting Education. Taylor \& Francis, 27(4), pp. 403-432. doi: 10.1080/09639284.2018.1490189.

Tanaka, S. and Sithole, M. (2015) 'Information Technology Knowledge and Skills Accounting Graduates Need Economics and Finance', International Journal of Business and Social Science, 6(8), pp. 47-52.

Tempone, I. , Kavanagh, M., Segal, N., Hancock, P., Howieson, B. and Kent, J. (2012) 'Desirable generic attributes for accounting graduates into the twenty-first century: The views of employers', Accounting Research Journal, 25(1), pp. 41-55.

Todd, P. A., Mckeen, J. D. and Gallupe, R. B. (1995) 'Job Skills : A Content Analysis of IS Job', Management Information Systems Research Center, University of Minnesota, 19(1), pp. 1-27.

Tsui, A., 2013. The spirit of science and socially responsible scholarship. Management and Organization Review, Cilt 9, pp. 375-394.

Vijayarani, S. and Janani, R. (2016) 'Text Mining: open Source Tokenization Tools - An Analysis', Advanced Computational Intelligence: An International Journal (ACII), 3(1), pp. 37-47. doi: 10.5121/ acii.2016.3104.

de Villiers, R. (2010) 'The incorporation of soft skills into accounting curricula : preparing accounting graduates for their unpredictable futures', Meditari Accountancy Research, 18(2), pp. 1-22.

Walker, S. P. (2008) 'Accounting histories of women: Beyond recovery?', Accounting, Auditing and Accountability Journal, 21(4), pp. 580-610. doi: 10.1108/09513570810872932.

Webb, J. and Chaffer, C. (2016) 'The expectation performance gap in accounting education: a review of generic skills development in UK accounting degrees', Accounting Education. Taylor \& Francis, 25(4), pp. 349-367. doi: 10.1080/09639284.2016.1191274.

Wells, P., Gerbic ,P., Kranenburg, I. and Bygrave, J..(2009) 'Professional skills and capabilities of accounting graduates: The New Zealand expectation gap?', Accounting Education, 18(4-5), pp. 403-420. doi: 10.1080/09639280902719390.

Wells, P. and Fieger, P. (2006) 'High school teachers' perceptions of accounting: an international study', Australian Journal of Accounting Education, 2, 1, 29-51.

Whiting, R. H. and Wright, C. (2001) 'Explaining gender inequity in the New Zealand accounting profession', British Accounting Review, 33(2), pp. 191-222. doi: 10.1006/bare.2001.0161.

Willcoxson, L., Wynder, M. and Laing, G. K. (2010) 'A whole-of-program approach to the development of generic and professional skills in a university accounting program', Accounting Education, 19(1-2), pp. 65-91. doi: 10.1080/09639280902886082.

Yaşar, Ş. (2019) 'Going Outside the Box: Competency-Focused Accounting Education', Muhasebe ve Finansman Dergisi, 510591(81), pp. 85-100. doi: 10.25095/mufad.510591. 
Yıldız, G. (2017) 'Accounting Professionals Vocational School Accounting Program Expectations Of Students: An Apllication Center Of Kayseri’, Muhasebe ve Finansman Dergis, 73, pp. 169-184.

Yürekli, E. and Gönen, S. (2015) 'Expectations of Accounting Professionals From Associate Degree Programs Regarding Development of Qualified Members of Accounting Profession', The Journal of KAU IIBF, 6(10), pp. 301-316. 
